\title{
UNIFICATION OF CRITERIA FOR THE ASSESSMENT OF GOOD FAITH IN NEGOTIATING CONTRACTS: FROM NATIONAL TO INTERNATIONAL THROUGH THE INTERCESSION OF THE EUROPEAN EXPERIENCE
}

\author{
M.C. Dobrilă
}

\section{Mirela Carmen Dobrilă}

Faculty of Law, Law Departament,

"Alexandru Ioan Cuza" University of Iași, Iași, Romania

*Correspondence: Mirela Carmen Dobrilă, Assistant PhD, Post-doctoral Researcher, "Alexandru Ioan Cuza" University of Iași, Boulevard Carol I, no. 11, Iași, Romania

E-mail: mirela.dobrila@uaic.ro

\section{Abstract}

This paper seeks to emphasize the idea and the efforts to unify the criteria for the assessment of good faith in the context of contract negotiation. In this regard, the paper observes the vision of the Romanian legislator regarding good faith in contract negotiation but also the existing vision at European level by highlighting links with existing coding projects at European contract law level and with other foreign civil codes in the context of certain aspects of comparative law.

Keywords: good faith, bona fides, unification, contract negotiation, European contract law, comparative law

\section{Introduction}

The absence of an express provision for good faith as a general principle in the previous Civil Code has been corrected through the amendment brought by the new Romanian Civil Code (NCC) (Law no. 287/2009, republished, in force since 2011 with the subsequent amendments and supplements) regarding good faith through the express regulation of this principle. Recognition (express this time) in the New Romanian Civil Code of the principle of good faith, as a general principle, is based also on the fact that this principle is expressly regulated in other foreign civil codes and drafted after the model of similar provisions in certain coding projects at the level of European contract law. Taking after the model of other foreign civil codes and the model of similar provisions in some coding projects from the European law of contracts, the Romanian legislature has chosen to introduce a separate text in respect to good faith when negotiating the contract, as an embodiment of the principle of good faith.

Good faith in contract negotiations: from national to international by through the intercession of the European experience

Although in the previous Romanian Civil Code (1864) good faith was not regulated as a general rule, based on the interpretation of the provisions within the Code relating to certain applications of good faith, it was concluded that good faith should be regarded as general rule.

Good faith is expressly regulated in the New Civil Code, Article 14 paragraph (1), under which any individual or legal person must exercise his rights and perform his civil duties in good faith, in accordance with public order and good morals. Reference is made to Article 11 NCC which stipulates that one can not be derogated from the laws that are of interest for the public order or good morals by agreement or unilateral legal acts. 
The reference to public order concerns the legal rules that protects a general interest. Moreover, the notion of good morals aims also for a general interest and signifies the entirety of rules imposed by a certain social morality which is a standard of human behavior ${ }^{1}$.

Starting from bona fides praesumitur of Roman law under Article 14 paragraph (2) NCC, good faith is presumed until proven otherwise. It is envisaged as a model the Article 2085 of the Civil Code of Quebec which provides that good faith is always presumed less when the law expressly requires to be proved. The new Romanian Civil Code enacts the concept of exercising rights and obligations in good faith in accordance with public order and good morals, then logically enshrines the postulate of good faith, under the form of a relative legal presumption with value until proven otherwise ${ }^{2}$.

By regulating good faith in the general part of the Civil Code, this Code aligns to most civil laws (eg. civil codes in Germany, Switzerland, Portugal, Spain, Poland, etc.) which establishes a legal presumption until proven otherwise ${ }^{3}$.

Article 1170 NCC regards the application of the principle of good faith in contractual matters. It is enshrined as a general subject the principle of good faith in the field of contract since the parties must act in good faith both at the negotiation and at the conclusion of the contract as well as throughout its execution, without being able to remove or limit the duty of good faith. In the previous Civil Code there was a provision relating to the execution of agreements in good faith, agreements obliging both to what is expressly provided but also for the consequences resulting from equity, custom or law (Article 970). Based on this text, naturally, good faith is considered as a principle that should govern all stages involving the conclusion and execution of the contract, including the time of negotiations.

The express regulation of the concept of good faith in Article 1170 of NCC extends the meaning of Article 970 previous Civil Code both in what concerns negotiation (obligation to inform) and of the period of its execution (contractual solidarism), the norm being imperative, without the possibility to derogate from its effects ${ }^{4}$. The regulation of Article 1170 NCC aligns to European trends from the contract field 5 .

As an actual application of the principle of good faith regulated by Article $14 \mathrm{NCC}^{6}$, Article 1183 NCC comes to outline the framework of action for good faith negotiations. Thus, good faith governs negotiations in the sense that the parties must act in good faith in the negotiations: the parties have the freedom of initiation, of conducting negotiations and breaking off negotiations and can not be held liable for their failure [Article 1183 paragraph (1) NCC]. All parties engaging in negotiations are required to comply with the requirements of good faith, this being a mandatory rule that can not be removed by agreement between the parties by limiting or excluding this obligation [Article 1183 paragraph (2) NCC].

Referring to good faith in negotiations, the rules in the contents of this obligation are the correct information, refraining from proposals clearly unacceptable that lead to breakage of negotiations, announcing the decision to end the negotiations for not holding the false hope of the partner, collaboration between parties so that negotiations should not exceed a

\footnotetext{
${ }^{1}$ P. Perju in F.A. Baias, E. Chelaru, Rodica Constantinovici, I. Macovei, Noul Cod civil. Comentariu pe articole, $1^{\text {st }}$ Edition, C.H. Beck Publishing House, Bucharest, 2012, p. 12;

${ }^{2}$ Idem, p. 15;

${ }^{3}$ Marilena Uliescu, Buna credință în Noul Cod civil, the Volume of the Workshop for scientific papers ,Justiție, Stat de drept și Cultură juridică”, The Institute for Legal Research "Acad. Andrei Rădulescu", Bucharest, 13 May 2011, Universul Juridic Publishing House, Bucharest, 2011, p. 362;

${ }^{4}$ Gh. Piperea, Introducere in dreptul contractelor profesionale, C.H. Beck Publishing House, 2011, Bucharest, p. 240; A. P. Dimitriu in A. G. Atanasiu, A. P. Dimitriu, A.F. Dobre et al. Noul Cod civil: note, corelații, comentarii, Publishing House, Bucharest, 2011, p. 448;

${ }^{5}$ Marilena Uliescu, op. cit., p. 364;

${ }^{6}$ A. P. Dimitriu, op. cit., p. 451;
} 


\section{M.C. Dobrilă}

reasonable duration, no involvement in parallel negotiations and keeping the confidentiality of information transmitted ${ }^{7}$.

It is contrary to the requirements of good faith the conduct of the party that initiates or continues negotiations with no intention to conclude the contract [Article 1183 (3) NCC]. Contrary to good faith in negotiations are unacceptable proposals, failure to respect the commitments, the omission of relevant information for the conclusion of the contract, but also other conducts may be considered contrary to good faith.

The behavior contrary to good faith in contractual negotiations characterized by initiation, continuation or breaking off negotiations contrary to good faith brings liability for the loss caused to the other party. In determining the loss, the New Civil Code allows a fairly broad interpretation: to see which is the loss one takes into account the costs incurred in order to be able to participate in negotiations, the waiver by the other party regarding other offers as by this waiver the party is denied the possible conclusion of a more favorable contract and any other similar circumstances.

Good faith during precontractual period involves the obligation of a conduct characterized by good faith in negotiating the contract or assumes the obligation to correct and complete information, respecting the interests of the negotiating parties and cooperation between parties. Such regulations, with similarities and differences exist in German, Italian, French law etc., unlike the English law where there is no general provision that should rule the obligation of good faith although there is "a duty to negotiate with care."

Good faith dominates all contractual steps by the fact that it first involves in the precontractual stage negotiations and second to the execution of contracts.

The concept of good faith in negotiations is rather unclear, also the way it is effectively applied is quite uncertain and without an actual shape. It is stated that those involved in negotiations may be sanctioned for certain bad faith behaviors used in negotiations (eg. use of negotiations in order to produce a delay or find out some secret information in another context), being still fairly difficult delineate what is accepted in relation to a particular standard regarding the truth ${ }^{9}$.

According to their will, the parties may supplement the primary obligation of good faith negotiation with a number of other accessory duties that respond to various concerns, including: the exclusiveness of negotiations with a certain partner in a given period of time, a sincerity clause ${ }^{10}$.

The solution of introducing specific provisions of good faith in negotiations in Article 1183 NCC cannot surprise as the Romanian legislature had already taken into consideration foreign models, for example, Article 2:301 of the Principles of European Contract Law (PECL) regarding Negotiations Contrary to Good Faith or those from Article 7 of the Gandolfi Code regarding the obligation to inform during contract negotiations but also the fact that many European civil codes enshrined the requirements of good faith in contract negotiations (eg. Article 1337 Italian Civil Code, Article 227 Portuguese Civil Code, Article 197 Greek Civil Code).

Most of the European Civil Codes contain general provisions regarding good faith, some of the codes contain specific provisions related to the concept of good faith while others contain provisions related to its application, but most systems make the distinction between

\footnotetext{
${ }^{7}$ M. Noşlăcan, Obligaţia negocierii cu bună-credinţă a contractelor, Yearly Journals of the West University of Timişoara, Law Series, no. 1-2/2008, p. 285, available at http://drept.uvt.ro/documents/Anale_UVT_Drept_12.2008_final-Obligatia-negocierii-cu-buna-credinta-a-contractelor.pdf;

${ }^{8}$ M. Uliescu, op. cit., p. 365;

${ }^{9}$ P. Reilly, Was Machiavelli Right? Lying in Negotiation and the Art of Defensive Self-Help, 24 Ohio State Journal on Dispute Resolution 481, 2009, p. 30, available at http://www.law.asu.edu/files/!NoTemplate/AALS /Reilly.pdf;

${ }^{10}$ M. Noşlăcan, op. cit., p. 286;
} 
the objective meaning of good faith and the subjective good faith: subjective good faith is defined as a subjective state of mind, not knowing nor having to know of a certain fact or event (with relevance in property law, bona fide acquisition), and objective good faith is the concept that the general good faith clauses refer to, it is regarded as a norm for the conduct of contracting parties, acting in accordance with or contrary to good faith ${ }^{11}$.

According to Article 1375 in the Civil Code of Quebec good faith shall govern the behavior of the parties, whether it be at the moment the obligation comes into existence, during its performance or the moment it is extinguished, while Article 6 states that each person shall exercise his/her civil rights according to the requirements of good faith. These articles are connected to Article 2 of the Suisse Civil Code, which has been interpreted so as to impose a duty of good faith during the pre-contractual period (Each person shall exercise his/her rights and execute his/her obligations according to the rules of good faith, and no manifest abuse of a right shall be protected by law) ${ }^{12}$. In the same way, Article 227 of the Portuguese Civil Code states that parties must act in good faith when negotiating and executing a contract. Article 197 of the Greek Civil Code provides that in the course of negotiations for the conclusion of a contract the parties shall be reciprocally bound to adopt the conduct which is dictated by good faith; Additionally, Article 198 states that a person, who in the course of negotiations for the conclusions of a contract has through his/her own fault caused damage to the other party, shall be liable for compensation even if the contract has not been concluded, and Article 288 imposes the fulfillment of the obligations from a concluded contract on the basis of good faith.

Good faith embodies a basic principle in the Italian law and the Italian Civil Code highlights its importance in various contractual stages: the parties must behave in good faith during the pre-contractual bargaining and contract drafting (Article 1337); contract must be interpreted in good faith (Article 1366); contract must be executed in good faith (Article 1375); in contracts providing for mutual counter-performance, each party can refuse to perform his obligation if the other party doesn't perform his own at the same time, unless different times for performance have been established by the parties or otherwise stipulated by the nature of the contract but performance cannot be rejected if, considering the circumstances, such rejection is contrary to good faith (Article 1460).

The Italian Civil Code of 1942 was the first code that codified the requirement of good faith in the contractual period of the negotiations, while the French Civil Code, the Belgium Civil Code and the Luxembourg Civil Code have not established such a requirement, although the courts in Belgium and France recognized the existence of a general principle of good faith that governs the stage of contract negotiations ${ }^{13}$.

The buona fede principle has been interpreted as a synonym of German Treu und Glaube even if the Italian case law seems still to place a lot of importance on the idea that the parties enter into a bargaining process under the principle of freedom of contract ${ }^{14}$.

In the Dutch law good faith is not defined, but Article 3:12 of the Civil Code of the Netherlands regarding the principle of reasonableness and fairness provides that in order to

\footnotetext{
${ }^{11}$ M. Hesselink, The Concept of Good Faith, in A. S. Hartkamp, M. W. Hesselink, E. H. Hondius, C. Mak, C. Edgar du Perron, Towards a European Civil Code, Fourth Revised and Expanded Edition, Kluwer Law International, 2010, p. 619-620, available at http://papers.ssrn.com/sol3/papers.cfm?abstract_id=1762630;

${ }^{12}$ B. Fauvarque-Cosson, D. Mazeaud, European Contract Law. Materials for a Common Frame of Reference: Terminology, Guiding Principles, Model Rules, Association Henri Capitant des Amis de la Culture Juridique Française, Société de Législation Comparée, 2008, p. 186, available at http://www.legiscompare.com/IMG/pdf/ CFR_I-XXXIV_1-614.pdf.

${ }^{13}$ Idem, p. 185;

${ }^{14}$ A. M. Musy, The Good Faith Principle in Contract Law and the Precontractual Duty to Disclose: Comparative Analysis of New Differences in Legal Cultures, International Centre For Economic Research, Working Paper no. 19 December 2000, p. 3, available at http://www.icer.it/menu/f_papers.html;
} 
determine the reasonableness and fairness one has to take into account the general accepted legal principles, the fundamental concepts of law in the Netherlands and the relevant social and personal interests which are involved in the given situation ${ }^{15}$.

German law distinguishes between Treu und Glauben (objective good faith) and Guter glaube (subjective good faith) ${ }^{16}$. Two meanings can be distinguished when speaking about good faith: the objective sense, good faith may be regarded as a method used to confer moral character contractual relationships, while the subjective sense provides that good faith aims to protect the erroneous belief and to give effect to appearance ${ }^{17}$.

In Germany, the principle of good faith and fair dealing marked an important breakthrough through $\S 242$ BGB which states that the duty to perform according to the requirements of good faith is by taking customary practice into consideration. This requires the party to perform in good faith, and this means to show proof of fairness (Treu) in the performance of obligation, to respect the legitimate reliance that he has engendered (Glauben), to take into account the legitimate interests of the other party ${ }^{18}$.

Good faith has been extended beyond a simple principle of performance and has become a general principle of good faith in German law becoming a central pillar of German law, and as a result, the principle of good faith also applies to the pre-contractual period ${ }^{19}$. As a general principle, good faith requires a positive or negative conduct, depending on the particularities of each contract. The German Civil Code contains no express provision on culpa in contrahendo or on neminem laedere, therefore good faith shall be applied as a general principle of law $^{20}$.

The condition of good faith during the period of precontractual negotiations has its origin in an article by Rudolph von Jhering (Culpa in contrahendo oder Schadensersatz bei nichtigen oder nicht zur Perfection gelangten Verträgen, Jahrbücher für die Dogmatik des heutigen römischen und deutschen Privatrechts, 1861): if a party determines the other to believe that the contract will be concluded, then such party is at fault, as a matter of culpa in contrahendo ${ }^{21}$.

The Swiss law, similar to German law, recognizes good faith as a general principle: according to Article 2 of the Swiss Civil Code, every person is bound to exercise his rights and fulfill his obligations according to the principles of good faith. Good faith has become a general principle of law and at the precontractual stage there is the precontractual liability for culpa in contrahendo, even in the absence of a written provision to this effect, because as soon as they enter into negotiations, the parties must behave in accordance with the rules of good faith and fair dealing, without causing any harm to the other ${ }^{22}$.

In French law, the case law and legal scholarship have established the principle of good faith as a general principle because the legal provisions concerning good faith were so few (Article 1116 of the Civil Code regarding prohibition on fraud, Article 1135 regarding equity in respect of implied obligations). According to Article 1134, paragraph 3 agreements must be performed in good faith; this article imposed a duty to conduct oneself in good faith, also at the precontractual stage. Although the principle remains that of freedom to break negotiations, the negotiations should be conducted in a fair way, according to good faith: the obligation to fairly inform the negotiating partner; it is prohibited to allow the other party to

\footnotetext{
${ }^{15}$ B. Fauvarque-Cosson, D. Mazeaud, p. 159;

${ }^{16}$ Idem, p. 196;

${ }^{17}$ Idem, p. 156;

${ }^{18}$ Idem, p. 519;

${ }^{19}$ Idem, pp. 519-520;

${ }^{20}$ Emanuela Iftime, Good Faith In Domestic Sales Law, Agora International Journal of Juridical Sciences, no. 4/2014, p. 72, available at http://univagora.ro/jour/index.php/aijjs/article/viewFile/1603/468;

${ }^{21}$ Fauvarque-Cosson, D. Mazeaud, p. 185;

${ }^{22}$ Idem, pp. 520-521;
} 
run up large costs with a view to a future contract and then harshly break off negotiation without reason; it is contrary to good faith and even sanctioned to encourage the expectations of the other party and then destroy them ${ }^{23}$.

There are certain comments to be made regarding the obligation of good faith in French law. There were critics regarding the fact that there is no provision on the applicability of the principle of good faith during the performance of the contract. Therefore, the liability rests on tort principles during pre-contractual negotiations and on contract principles once the contract is formed ${ }^{24}$.

Unlike in German or Italian law, and like in French law, no special rule of precontractual liability (culpa in contrahendo) exists in English law when no Contract results $^{25}$. Like in France, Legal duties may arise between negotiating parties in tort: parties may owe duties of care to each other ${ }^{26}$. The place of good faith in English law remains controversial with a direct impact on the law of precontractual negotiations, as any requirement of good faith in such negotiations to enter into a contract would not be possible if a similar requirement is not present in the performance of a valid contract ${ }^{27}$. Despite several critical views to the contrary, English law still refuses to imply general duties of good faith, fair dealing, disclosure and confidentiality at the negotiating stage; in this, it still offers a clear alternative to EU Commission's Common Frame of Reference, the Principles of European Contract Law, the UNIDROIT Principles of International Commercial Contracts, all of which endorse broadly similar versions of a general duty of good faith and fair dealing in negotiating contracts $^{28}$.

Good faith is often connected with moral standards and considered a moral standard itself, meaning that a party should take the interest of the other party into account. Some systems do not distinguish between equity and good faith, they regard them as the same objective standard. ${ }^{29}$

Good faith and fair dealing is one of the fundamental ideas underlying the UNIDROIT Principles of International Commercial Contracts 2010: Article 1.7 provides in general terms that each party must act in accordance with good faith and fair dealing in international trade and the parties may not exclude or limit this duty; even in the absence of special provisions in the Principles the parties' behavior throughout the life of the contract, including the negotiation process, must conform to good faith and fair dealing ${ }^{30}$.

According to article 2.1.15 of the UNIDROIT Principles regarding the Negotiations in bad faith, a party is free to negotiate and is not liable for failure to reach an agreement, but a party who negotiates or breaks off negotiations in bad faith is liable for the losses caused to the other party. It is considered for a party to enter into or continue negotiations in bad faith when there is no intention to reach an agreement with the other party. A party's right to freely enter into negotiations and to decide on the terms to be negotiated must not be in conflict with the principle of good faith and fair dealing ${ }^{31}$. Other cases of negotiations in bad faith are found

\footnotetext{
${ }^{23}$ Idem, pp. 525-526.

${ }^{24}$ E. Iftime, op. cit., p. 71.

${ }^{25}$ S. Banakas, Liability for Contractual Negotiations in English Law: Looking for the Litmus Test, Revista para el análisis del derecho indret no. 1/2009, p. 4, available at http://www.indret.com/pdf/605_en.pdf;

26 A. M. Musy, The Good Faith Principle in Contract Law and the Precontractual Duty to Disclose: Comparative Analysis of New Differences in Legal Cultures, International Centre For Economic Research, Working Paper no. 19 December 2000, p. 7, available at http://www.icer.it/menu/f_papers.html;

${ }^{27}$ S. Banakas, op. cit., p. 5;

${ }^{28}$ S. Banakas, op. cit., pp. 16-17;

${ }^{29}$ M. Hesselink, op. cit., p. 622;

${ }^{30}$ International Institute for the Unification of Private Law (UNIDROIT). UNIDROIT - Principles Of International Commercial Contracts 2010, Rome, p. 19, available at http://www.unidroit.org/english/principles/contracts/ principles2010/integralversionprinciples2010-e.pdf;

${ }^{31}$ Idem, pp. 59-60;
} 


\section{M.C. Dobrilă}

when a party has misled intentionally or through negligence the other party on the nature or terms of the contract or by misrepresentation of facts or by failing to communicate issues that had to be communicated.

The aggrieved party may recover the expenses incurred in the negotiations and may also be compensated for the lost opportunity to conclude another contract with a third person, but may generally not recover the profit which would have resulted had the original contract been concluded ${ }^{32}$.

The principle of good faith requires the compliance with a minimum standard of loyalty by the contracting parties ${ }^{33}$. At the level of the Principles of European Contract Law drafted by the Lando Commission (PECL) ${ }^{34}$, according to Article 1:201, each party must act in accordance with good faith and fair dealing and the parties may not exclude or limit this duty. According to Article 2:301 regarding Negotiations Contrary to Good Faith (regulated in section 3 regarding Liability for negotiations) it is contrary to good faith and fair dealing for a party to enter into or continue negotiations with no real intention of reaching an agreement with the other party. A party is free to negotiate and is not liable for failure to reach an agreement, but if the party negotiated or broke off negotiations contrary to good faith and fair dealing, she/he is liable for the losses caused to the other party .

In DCFR - Draft Common Frame of Reference, the Study Group on a European Civil Code and the Research Group on EC Private Law (Acquis Group) identified as main principles: contractual freedom; contractual security and contractual loyalty (liberté contractuelle; sécurité contractuelle; loyauté contractuelle), the latter as a duty to act in conformity with the requirements of good faith and fair dealing, from the negotiation of the contract until all of its provisions have been given effect ${ }^{35}$.

Article I.-1:103 regarding good faith and fair dealing is placed in Book I entitled General Provisions in DCFR Model Rules, as a general principle; good faith and fair dealing refers to a standard of conduct characterized by honesty, openness and consideration for the interests of the other party to the transaction or relationship in question" (paragraph 1) and it is contrary to good faith and fair dealing for a party to act inconsistently with that party's prior statements or conduct when the other party has reasonably relied on them to that other party's detriment (paragraph 2) ${ }^{36}$.

DCFR regulates the duty to negotiate in accordance with good faith and fair dealing and not to break off negotiations contrary to good faith and fair dealing and this duty may not be excluded or limited by contract. According to Article II. - 3:301 regarding negotiations contrary to good faith and fair dealing, a person is free to negotiate and is not liable for failure to reach an agreement. The person who is in breach of this duty is liable for any loss caused to the other party. It is considered contrary to good faith and fair dealing for a person to enter into or continue negotiations with no real intention of reaching an agreement with the other party $^{37}$.

\footnotetext{
${ }^{32}$ Idem, p. 60;

${ }^{33}$ C. Macovei, Unificarea dreptului contractelor. O perspectivă europeană. Junimea Publishing House, Iasi, 2005, p. 121.

${ }^{34}$ O. Lando, H. Beale, Principles of European Contract Law (PECL), Parts I and II. Commission on European Contract Law. Kluwer Law International, Hague, Netherlands, 2000.

${ }^{35}$ C. von Bar, E. Clive, H. Schulte-Nölke, H. Beale, J. Herre, J. Huet, M. Storme, S. Swann, P. Varul, Anna Veneziano, F. Zoll, Principles, Definitions and Model Rules of European Private Law, Draft Common Frame of Reference (DCFR), Outline Edition, The Study Group on a European Civil Code and the Research Group on EC Private Law (Acquis Group), Sellier European Law Publishers, Munich, 2009, p. 11-12, available at http://ec. europa.eu/justice/policies/civil/docs/dcfr_outline_edition_en.pdf;

${ }^{36}$ Idem, p. 178;

${ }^{37}$ Idem, pp. 193-194;
} 
Regarding good faith in Common Frame of Reference (Projet de cadre commun de référence), in the documents prepared by Association Henri Capitant des Amis de la Culture Juridique Française and the Société de Législation Comparée, entitled Terminology, Guiding Principles, Revised version of the Principles on European Contract Law, the contractual fairness, as guiding principle (among other principles like freedom of contract, contractual certainty) involves, firstly a general obligation to act in good faith and fair dealing (Article 0301) and secondly an obligation to perform the contract in good faith (Article 0-302). The general obligation of good faith and fair dealing (Article 0-301) provides that the parties must act in good faith and fair dealing from the negotiation of the contract until all of its provisions have been given effect with no possibility to exclude this duty, nor limit it. Complementary, the obligation of performing the contract in good faith provides that each party is required not to do anything that prevents the performance of the contract or that infringes the rights that the other party acquires from the contract, recognizing the possibility of renegotiating the contract in case a party acts in such a way as to reduce the benefit that the other party within the concluded contract (Article 0-302) ${ }^{38}$.

Good faith and fair dealing presides over contractual negotiations: Article 2:301 (2) provides that a party who has negotiated or broke off negotiations contrary to good faith and fair dealing is liable for the losses caused to the other party; Article 2:301 (3) establishes the fact that a party starts or pursues the negotiations with no real intention of reaching an agreement with the other party is contrary to the requirements of good faith and fair dealing. In addition, even after the contract is entered into, the obligation to negotiate in good faith continues to apply should the contract have to be renegotiated: Article 6:111 (3) provides that damages may be awarded for the loss suffered by a party if the other party refuses to negotiate or breaks off negotiations which practically is contrary to good faith and fair dealing ${ }^{39}$.

Regarding good faith in precontractual negotiation, according to Article 6 of the European Contract Code developed by the Pavia Group - the Academy of European private lawyers (Gandolfi Code or Pavia Contract Code), the parties are free to undertake negotiations without being held at all responsible if the promised contract is not concluded, unless their behavior is contrary to good faith [paragraph (1)]. It is contrary to good faith to enter into or to continue negotiations with no real intention of concluding a contract [paragraph (2)].-Either party who breaks off negotiations without justifiable grounds, having created reasonable confidence in the other, is acting contrary to good faith [paragraph (3)]. The party who acted contrary to good faith shall be liable for the harm it has caused to the other party (the costs incurred in the negotiations, the loss of opportunities caused by the negotiations underway) [paragraph (4) ${ }^{40}$.

The regulation embodying a general principle of the good faith principle in contract law gives expression to the guiding principle of contractual loyalty under the Principles of European contract law. The guiding principle of contractual loyalty is binding and contractual loyalty covers the duty of good faith, meaning a good contractual behavior, making out of good faith a rule of conduct. Moreover, the terms of good faith and loyalty can be synonymous $^{41}$.

Good faith is a notion that comes to show clearly the fact that there are difficulties linked to divergence of concepts because although the notion of good faith is known in all European Union countries, the French notion la bonne foi does not identify with the English good faith or with the German Treu und Glauben or the Italian bouna fede, thus the European

\footnotetext{
${ }^{38}$ B. Fauvarque-Cosson, D. Mazeaud, pp. 515-570;

${ }^{39}$ Idem, p. 516;

${ }^{40}$ Pavia Group, European Contract Code, Accademia Dei Giusprivatisti Europei (the Academy of European private lawyers), 2004, p. 3, available at http://www.eur contrats.eu/site2/docs/EuropeanContr.pdf;

${ }^{41}$ M. Uliescu, op. cit., p. 364;
} 
efforts being difficult in drafting a text containing the contractual common law ${ }^{42}$, including in what concerns the content and the application of good faith in the precontractual stage, in the contractual negotiations.

Regarding the obligation to negotiate in good faith the search of a definition to explain the content of this obligation is useless, because it can not have content only a posteriori, after the decision taking, its limits being observed only in particular cases ${ }^{43}$.

\section{Conclusions}

Express dedication of the principle of good faith in Article 14 of the New Romanian Civil Code and its express recognition as a general principle, along with other provisions which come to complete the application framework of this principle (Article 1170 of good faith during the negotiation, conclusion and execution of contract, Article 1183 regarding good faith in contractual negotiations) was based on the model containing the principle of good faith at European level, either through the considerable importance the German law gives to good faith in the contractual relationships and to the trust established between the parties to the commencement of the contractual negotiations ${ }^{44}$ (by enshrining good faith by Article $\$ 242$ BGB, with the distinction between objective good faith Treu und Glauben and the subjective good faith Gute Glaube) or as a general principle in PECL or other coding projects at the European level or in other civil codes.

The importance of the principle of good faith to our legal system allows good faith to be seen as a general obligation, and the current role of good faith is recognized by the Romanian legislature in the New Civil Code.

*This work was supported by the strategic grant POSDRU/159/1.5/S/ 141699, Project ID 141699, co-financed by the European Social Fund within the Sectorial Operational Program Human Resourses Development 2007-2013.

Bibliography:

1. Emanuela Iftime, Good Faith In Domestic Sales Law, Agora International Journal of Juridical Sciences, no. 4 /2014, available at http://univagora.ro/jour/index.php/aijjs/article/ viewFile/1603/468;

2. P. Perju in F.A. Baias, E. Chelaru, Rodica Constantinovici, I. Macovei, Noul Cod civil. Comentariu pe articole, $1^{\text {st }}$ Edition, C.H. Beck Publishing House, Bucharest, 2012;

3. Marilena Uliescu, Buna credință în Noul Cod civil, Volumul Sesiunii de comunicări științifice „Justiție, Stat de drept și Cultură juridică”, Institutul de Cercetări Juridice "Acad. Andrei Rădulescu", București, 13 mai 2011, Universul Juridic Publishing House, Bucharest;

4. A.P. Dimitriu in A.G. Atanasiu, A.P. Dimitriu, A.F. Dobre et al,. Noul Cod civil: note, corelații, comentarii, Publishing House. Bucharest, 2011;

5. Gh. Piperea, Introducere în dreptul contractelor profesionale, C.H. Beck Publishing House, Bucharest, 2011;

6. International Institute for the Unification of Private Law (UNIDROIT). UNIDROITPrinciples Of International Commercial Contracts 2010, Rome, available at http://www.unidroit.org/english/principles/contracts/principles2010/integralversionprinciples2 010-e.pdf;

7. M. Hesselink, The Concept of Good Faith, in A. S. Hartkamp, M. W. Hesselink, E. H. Hondius, C. Mak, C. Edgar du Perron, Towards a European Civil Code, Fourth Revised and

\footnotetext{
${ }^{42}$ C. Macovei, op. cit., p. 88 ;

${ }^{43}$ M. Noşlăcan, op. cit., p. 286;

${ }^{44}$ C. Macovei, op. cit., p. 65.
} 
Expanded Edition, Kluwer Law International, 2010, available at http://papers.ssrn. com/sol3/papers.cfm?abstract_id=1762630;

8. C. von Bar, E. Clive, H. Schulte-Nölke, H. Beale, J. Herre, J. Huet, M. Storme, S. Swann, P. Varul, Anna Veneziano, F. Zoll, Principles, Definitions and Model Rules of European Private Law, Draft Common Frame of Reference (DCFR), Outline Edition, The Study Group on a European Civil Code and the Research Group on EC Private Law (Acquis Group), Sellier European Law Publishers, Munich, 2009, p. 11-12, available at http://ec. europa.eu/justice/policies/civil/docs/dcfr_outline_edition_en.pdf;

9. P. Reilly, Was Machiavelli Right? Lying in Negotiation and the Art of Defensive SelfHelp, 24 Ohio State Journal on Dispute Resolution 481, 2009, available at http://www. law.asu.edu/files/!NoTemplate/AALS /Reilly.pdf;

10. S. Banakas, Liability for Contractual Negotiations in English Law: Looking for the Litmus Test, Revista para el análisis del derecho indret no. 1/2009, available at http://www.indret.com/pdf/605_en.pdf;

11. B. Fauvarque-Cosson, D. Mazeaud, European Contract Law. Materials for a Common Frame of Reference: Terminology, Guiding Principles, Model Rules, Association Henri Capitant des Amis de la Culture Juridique Française, Société de Législation Comparée, 2008, available at http://www.legiscompare.com/IMG/pdf/CFR_I-XXXIV_1-614.pdf;

12. M. Noşlăcan, Obligaţia negocierii cu bună-credinţă a contractelor, Analele Universității de Vest din Timișoara, Law Series, no. 1-2/2008, available at http://drept.uvt.ro/ documents/Anale_UVT_Drept_1-2.2008_final-Obligatia-negocierii-cu-buna-credinta-acontractelor.pdf;

13. C. Macovei, Unificarea dreptului contractelor. O perspectivă europeană. Editura Junimea, Iasi, 2005;

14. Pavia Group, European Contract Code, Accademia Dei Giusprivatisti Europei ((the Academy of European private lawyers), 2004, p. 3, available at http://www.eur contrats.eu/site2/docs/EuropeanContr.pdf;

15. A.M. Musy, The Good Faith Principle in Contract Law and the Precontractual Duty to Disclose: Comparative Analysis of New Differences in Legal Cultures, International Centre For Economic Research, Working Paper no. 19 December 2000, available at http://www.icer.it/menu/f_papers.html;

16. O. Lando, H. Beale, Principles of European Contract Law (PECL), Parts I and II. Commission on European Contract Law. Kluwer Law International, Hague, Netherlands, 2000 . 